\title{
A NEW DAY OF HOPE: IOWA COMMISSION FOR THE BLIND
}

\author{
by a Staff Member \\ The lowa Commission for the Blind
}

A history of an organization or agency with which a substantial segment of the readers are unfamiliar requires a definition. The Iowa Commission for the Blind can be defined in at least two ways. It can be termed simply "a state agency established to give services to blind persons who live in Iowa." It can also be defined as "a state agency serving the blind of Iowa, generally considered to be the finest and most successful agency of its type in the world."

Both definitions are correct. But the second one has been valid only during the past decade, less than one quarter of the Commission's 43 years of existence.

The legal steps necessary for the creation of what has since become a unique agency were taken in the spring of 1925 by the 4lst General Assembly of Iowa. The legislators passed a law creating a three-member commission which would hire an executive director and necessary assistants.

Among other things, the law directs the Commission to maintain a complete register of the blind, act as a bureau of information and industrial aid, assist in marketing the products of blind workers, establish workshops and provide vocational training, and discourage begging.

The Legislature appropriated $\$ 20,000$ for the biennium; an executive secretary, stenographer, home teacher and saleswoman were hired, and the Commission was off and running $\ldots$ at its own pace.

The pace at which agencies for the blind moved in the 1920 's was hardly faster than that of the proverbial snail. And while we can assume the snail eventually gets to where he is going, the programs for the blind seldom accomplished their meager goals. Except in a few isolated instances, the philosophy that the blind could and should take their rightful and productive place in society was non-existent. 
The thrust of programs for the blind was aimed at providing some work in the home, reducing idleness and allowing the worker to earn a few dollars a month. Sewing and weaving were typical of the work. Outside of the home there were a few workshops, supposedly to provide training which would enable the blind to assume regular jobs. But in most cases the workers remained there permanently, caning chairs, and making brooms, also earning a very few dollars a month.

At best the agencies occasionally attempted to help set up a blind man in a small business for himself. Thus, the minutes of the Jan. 11, 1927 meeting of the Iowa Commission for the Blind show that "The Executive Secretary was authorized to purchase a popcorn wagon at $\$ 65.15$ for the use of Richard Wheeldon, intelligent blind man of Des Moines who has shown great initiative in carrying on, Mr. Wheeldon in turn to buy the wagon on installments from the Commission."

But for the most part, the blind continued to vegetate in their homes, in idleness or near idleness. And this situation continued in Iowa, not only during the 1920s, but for the following three decades. The only exception was a brief flurry of activity during World War II, when the dire need for manpower sent a number of blind workers into war plants.

While the activities of the Commission continued on a minimal and unimaginative basis, the philosophy stressing the abilities of the blind, rather than their disabilities, began to take hold among the blind themselves in the 1940s. And by the mid-1950s there were enough effective programs around the nation so that the organized blind of Iowa-the Iowa Association of the Blind (I.A.B.) - began to make louder and louder demands for something better in the Hawkeye State.

The increasing dissatisfaction of the blind themselves led to some increase in activity by the Commission. The minutes of the Sept. 16, 1957 meeting show that a committee for evaluating educational plans for blind school children was approved, that eight vocational rehabilitation plans had been approved and two employment placements had been made since the previous July 1st, and that an outline for a staff development program was approved. By March of the 
following year the Commission decided tentatively to ask the 1959 Legislature for an appropriation of $\$ 270,000$ to $\$ 280,000$, a far cry from the original $\$ 20,000$ biennial budget.

But much of this was in the nature of being "too little and too late," and the ever louder outcry of the organized blind led to a meeting between the Commission and the president and five members of the I.A.B., at which "the Director pointed out that even with the expanded staff, service could not now be extended to all of the blind in the state in need of social and vocational rehabilitation services, additional counsellors and home teachers were needed."

The plant in which the Commission was housed was alone indicative of the sad state of affairs. Although the Commission started out in the State House, it was moved to three small rooms in the Amos Hiatt Building, a former schoolhouse repeatedly condemned by the fire marshal.

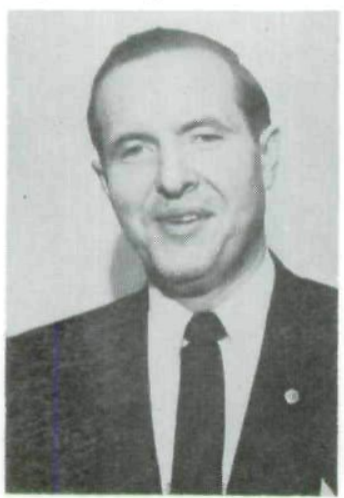

Kenneth Jernigan

But the turning point in the fortunes of the Commission and the Blind of Iowa was fast approaching. It came on April 21, 1958, when Kenneth Jernigan assumed the executive directorship of the Commission. Mr. Jernigan had been a teacher at the California Orientation Center for the Blind near Oakland. He was also a vice president of the National Federation of the Blind, the largest organization of the blind. But of more significance, he was one of the leading proponents of the "new" philosophy that blind people are normal people who cannot see. Or put in more practical terms, "Given the proper training and opportunity, the average blind person can perform the average job in the average place of business."

The Spring of 1958 marks the end of the first era of the Iowa Commission for the Blind, and the start of the second era. Because of what has transpired since that date, any narrative of the second era must, of necessity, center around Jernigan. 
One of his first acts was to compile a summary and evaluation of the Commission. Presented to the Commission members two weeks after he assumed his post, the document was nothing less than a damning indictment of past failings and failures:

The performance and morale of the agency are at an unbelievably low level. . The physical setup alone is sufficient to explain the low morale of the staff, the internal friction and bickering, the general feeling of depression and lack of optimism. . There is a total lack of organization throughout the agency. . Past appropriations for the Commission have been astoundingly meager, and even these have not been properly used. . Salaries paid by the agency have always been as low as the traffic would bear, and the state has just about got what it paid for."

The evaluation went on to criticize the small number of vending stands for the blind, the nearly non-existent Home Teaching services, the unsatisfactory program of Home Industries for the Blind, and the low rate of rehabilitations of newlyblinded Iowans. It pointed to the figures of the Federal Office of Vocational Rehabilitation (OUR) which showed Iowa ranking 48th among the then 48 states in the number of blind persons rehabilitated per 100,000 of total population. This was just one item in an OVR survey and led to increased agitation by the blind for better programs.

The evaluation concluded: "It is not an exaggeration to describe the present situation as desperate. The blind of the state are receiving practically no services at all, and they cannot receive any unless there is a complete reorganization of the Commission. Without more money and more space the agency simply cannot function. Present funds are largely being wasted."

Jernigan then went on to recommend far more space for the Commission, and more funds for higher salaries, additional personnel and a substantial expansion of the program. Here it should be noted that the lack of funds was not attributable to the legislature or the governor's office. The fault lay with past Commission members who had not been sufficiently 
alarmed to press for a new and expanded program. He concluded the recommendations by urging that he be fired if they are adopted and he did not show results within a reasonable time.

Less than two months later, on July 1,1958 , began fiscal year 1959, the first year of substantial progress in correcting former inadequacies. It also marked the first full year of progress toward pre-eminence.

On the practical side, the State Executive Council granted the Commission nine offices, instead of three, and authorized a staff of 19, including 13 professionals. This compared with a total staff of eight in fiscal year 1957. The vending stand and small business enterprises programs were completely reorganized. Of great portent for the future, negotiations were begun with the Library of Congress for the establishment of a regional library in Iowa. A new Home Industries program was begun and the existing programs were modernized.

Of great importance, 26 blind Iowans were rehabilitated during the year, compared with 12 in fiscal year 1957, and many more were placed in schools or training situations. It was also during fiscal year 1959 that the Commission succeeded in placing Iowa's first blind teacher in a regular public school classroom situation, and the first blind executive with the Allis Chalmers firm.

While the Executive Council temporarily alleviated the Commission's space problems, the 1959 Legislature made possible a milestone in Iowa's program for the blind by appropriating $\$ 300,000$ to purchase a building to be used as an orientation center and an additional $\$ 500,000$ was made available in state and federal funds for remodeling, alterations, and equipment. The structure, which is the present home of the Commission, was formerly the YMCA at Fourth and Keosauqua Way in Des Moines. Its ultimate acquisition was one of the major factors in developing Iowa's first adequate and well-rounded program of service to the blind.

In areas outside of state government, there were strengthened ties with the Lions Clubs, the organized blind, parents of blind chldren, and the women's volunteer groups who transcribe books for the blind. An additional and unique 
source of transcription was established in 1959 when a program was started involving prisoners at the State Penitentiary in Fort Madison. The new program not only benefited the blind college students who received the books, but introduced a positive factor in the prisoners' rehabilitation.

However, the basic change brought about in fiscal year 1959 was one of philosophy. The protective restrictions of the past that limited opportunities and defeated the very purposes of the Commission were replaced by the beliefs that the blind are normal people with a physical nuisance to overcome and that equality of opportunity will lead to the blind citizen's complete economic and social integration.

The first full year was ended. In his report to the Commission, Jernigan concluded: "There is now every indication that the future holds a bright promise and that a new day of hope for the blind of Iowa is dawning."

The beginning of the move to the Commission's own building at Fourth and Keo highlighted fiscal year 1960. Plans for the six-story building called for the basement to contain shops, and a swimming pool, already existing. The first floor would contain administrative offices, a telephone operator training area, a snack bar and grill open to the public and serving as a training facility, a student recreation lounge, and gymnasium facilities. The home industries department, a complete home economics training area and a large dining room for students would be located on the second floor. The third floor would house rehabilitation offices, conference rooms, testing rooms, and trainees classrooms. The fourth floor would be completely occupied by the library facilities, while the fifth and sixth floors would contain the trainees' bedrooms-women on the fifth, men on the sixth-plus apartments for necessary supervisory staff personnel.

The plans were carried out, and the fact that virtually no corrective changes have had to be made in the nearly ten years that have passed attests to their soundness.

But even before the move to the building began, Iowa's first orientation and adjustment classes for the blind were inaugurated in the old Amos Hiatt Building on Nov. 2, 1959. At first there were only three students and two teachers, but 
there was a waiting list of approximately 125 eligible blind who wanted training. Because of the limited space in the Hiatt building the initial instruction was confined to Braille, typing, travel training and personal grooming. But these were supplemented by visits to local homes, where students used borrowed kitchens and utensils for home economics instruction. Students learned their travel techniques around the State Capitol grounds, in fair, rainy, and snowy weather.

When the Commission moved into its new center on Feb. 1,1960 , the remainder of the courses were added to the orientation curriculum. The Commission building not only offered adequate space, but an ideal location for travel training instruction and practice. The nearness of transportation depots, restaurants, and stores gave students an incentive to learn to travel by themselves and made it possible to plan a variety of travel problems and situations. The sight of blind people efficiently and independently making their own way with their white canes soon became familiar to the office workers and shoppers in downtown Des Moines. By the end of the fiscal year, June 30 , the orientation course contained 15 students and four instructors.

However, the prime objective of the Commission is rehabilitation, which can simply be defined as the process ending in the employment of a blind person. Forty blind Iowans were rehabilitated in fiscal year 1960, compared with 26 the previous year. These included a construction worker, a parts packer, a machine operator in an industrial plant, a darkroom technician and a nurse's aide.

Another significant development in fiscal year 1960 was the final decision to establish a regional library for the blind in Iowa at the Commission. With the help of Iowa Congressmen, negotiations were completed with the Library of Congress, and the setting up of the library was begun.

1960 also saw the establishment of a second district office, in Waterloo. The first branch office had been established several years earlier in Cedar Rapids.

The new era for the blind of Iowa was made possible by the hiring of Jernigan two years earlier. But with the Commission moving into its own six-story building at 4 th and Keosququa, that new era began in earnest. 
As the fiscal year ended, Jernigan said, "It is the belief of the Commission that it will not be many years before Iowa has one of the truly outstanding programs in the nation ..."

The Commission's belief was soon to become a reality, perhaps even more rapidly than Jernigan and the Commission members had dared to hope.

Fiscal year 1961 saw the completion of the Commission's build-up in its new quarters and the beginning of total services in its new program. Near the end of the fiscal year, on June 10, 1961, the Center for the Blind was officially dedicated. The cornerstone of the program, a total resource building, was now in full operation.

One of the most important resources that began operation in 1960 was the regional library. In the past, blind Iowans had been served by the regional library in Jacksonville, Ill. But this service had continually deteriorated, until by 1960 many Iowans simply discontinued their patronage.

With the establishment of the library at the Commission and the hiring of Florence Grannis as chief librarian, these conditions were rapidly reversed. The facility was soon stocked with thousands of books, both in Braille and "talking book" (phonograph disc) form, supplemented by books tape recorded and Brailled by volunteer groups for students.

The end of fiscal year 1961 found 21 students in the orientation course, compared with 15 a year earlier. Forty-four blind Iowans were rehabilitated and placed in jobs during the year, a ten percent increase over the previous year. At the end of the year there were 221 blind Iowans receiving rehabilitation services from the Commission, bringing closer the goal of having every employable blind person in the state working at his or her full potential.

As the 1960s marched onward, so did the Commission program and its results. It started with the hiring of a new director in the late 1950s. In the early 1960s the facilities came into being. With the proper tools and personnel to handle them, the Commission program has moved ahead rapidly and continuously, with one success story after another, since the early part of the decade. 
The number of rehabilitated blind Iowans has shown a steady increase. Twelve were rehabilitated in fiscal year 1957. The figure for last year was 90 . Even more startling is the type of jobs now being performed by blind Iowans. The graduates of the rehabilitation program include electrical engineers and computer programmers.

As the number of gainfully employed blind persons increases, the number of those on public assistance has been reduced. . from nearly 1500 in 1957 to less than a thousand in 1969.

The growth of the Commission's library was spectacular, and by 1967 it became the largest library for the blind in the world. But even earlier, the American Library Association presented its national award to Jernigan for his pioneering efforts and in 1967 awarded him the Francis Joseph Campbell Citation for Outstanding Contributions to Library Service for the Blind.

The library's staff of 27 , including four professional librarians, is the largest of any regional library in the nation. But the best measurement of a library's effectiveness is its service: it now has more than 4,400 readers, compared with less than 700 when it was first established, and its circulation has risen from 43,000 in 1961 to more than 200,000 in 1969. In 1966, six years after its establishment, the library sent out its 500,000th book. In October, 1969, three years later, the millionth book went out. Of great significance to Iowa students is the fact that volunteers transcribe more books for the library than the combined total of all the other regional libraries.

But statistics only tell part of the Commission's successful history of the past decade. In 1965 the South Carolina State Legislature decided the blind program in the Palmetto State needed to be improved. After a legislative committee inspected the Iowa Commission facilities, the South Carolina program was remodeled on the Iowa pattern.

Two years later the State of Idaho adopted the Iowa model in establishing its new programs for the blind. The programs 
in two states are headed by graduates from the Iowa Commission, while other graduates and former staff members are now part of the programs in other states.

On March 11, 1968, the Commission's progress during the past decade received special recognition from the White House. A special award from the President of the United States was presented to Jernigan by Harold Russell, Chairman of the President's Committee on Employment of the Handicapped, for "a remarkable story of institutional rebirth and transformation within the space of one decade..."

Russell said, "The implications of this model state program of services, not just for the blind but for all disadvantaged people of our nation and of the world, are so momentous that the President of the United States, Lyndon B. Johnson, has expressed his personal desire to give recognition and support to the Iowa Commission for the Blind and its Director."

More national recognition, this time from the organized blind themselves, came to Jernigan a few months later when he was elected President of the National Federation of the Blind.

Back on the Iowa scene, the 1969 Legislature paid what could be considered the ultimate compliment to Jernigan and the Commission. The session was an economy session, and of more than 100 state agencies, the Iowa Commission for the Blind was the only one to be granted its full budget request.

Recognition came from not only the state and nation, but from foreign lands as far away as Ceylon and India. This began in 1964 when representatives from 12 foreign countries came to Des Moines to study the Iowa Commission's program as a model, and the stream of foreign visitors has continued steadily.

But in the long run, one fact overshadows all of the recognition and citations and awards. . the greatest tribute to the leadership of Jernigan and the work of the Iowa Commission for the Blind lies in the fact that in Iowa-far more than in any other state- the blind are beginning to be regarded as simply "normal people who cannot see." 
Copyright of Annals of Iowa is the property of State of Iowa, by \& through the State Historical Society of Iowa and its content may not be copied or emailed to multiple sites or posted to a listserv without the copyright holder's express written permission. However, users may print, download, or email articles for individual use. 